\title{
The Regulation of Insider Trading as an Agency Problem ${ }^{1}$
}

\author{
Alexandre Padilla* \\ The Metropolitan State College of Denver, Department of Economics, Campus Box 77, \\ P.O. Box 173362, Denver, CO 80217-3362
}

\begin{abstract}
This paper attempts to shed a new light on the insider trading issue by studying the unintended effects of insider trading laws. It shows that government regulation of insider trading can actually make the problems it intends to resolve worse. More particularly, this paper shows that insider trading laws instead of mitigating the agency problems that have been associated with insider trading actually can aggravate them by hindering the effectiveness of governance mechanisms existing within and outside the corporation.
\end{abstract}

JEL classification: D820, G380, K220.

Keywords: Active Shareholding; Agency Problem; Information; Insider Trading; Government Regulation.

\footnotetext{
${ }^{1}$ The title of this paper has been chosen in reference to Judge Easterbrook's paper entitled "Insider Trading as an Agency Problem" (1985).

* Alexandre Padilla is Assistant Professor of Economics at the Metropolitan State College of Denver. Contacting Author Information: Tel. 303-556-3131; fax: 303-556-3966.

Email address: padilale@,mscd.edu (Alexandre Padilla)
} 


\section{TABLE OF CONTENTS}

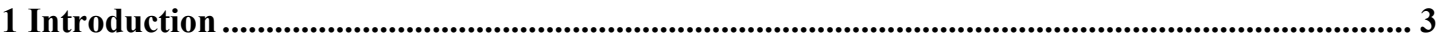

2 Insider Trading as Agency Problem ......................................................................................... 3

3 The Unintended Effects of Insider Trading Laws within the Corporation ................................... 5

3.1 The Importance of Active Shareholding within the System of Corporate Governance............... 5

3.2 The Effects of Insider Trading Laws on Active Shareholding........................................... 5

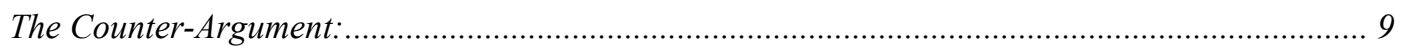

3.3 Collusion, Bribery, and Information Disclosure .................................................... 9

4 How Insider Trading Laws Affect Corporate Governance Outside the Firm .............................. 11

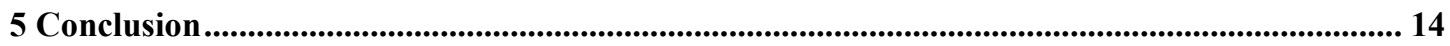




\section{Introduction}

A classic economic argument advanced in favor of prohibiting insider trading ${ }^{2}$ is that it gives rise to agency problems. The ability to access material nonpublic information about the corporation and profit from swings in corporation's stock prices provides insiders with incentives to maximize their own welfare at the expense of corporation's shareholders.

This paper addresses this argument and shows that insider trading laws can actually make the problems they intend to resolve worse. It shows that insider trading laws aggravate the agency problems associated with insider trading. Insider trading laws hinder the effectiveness of governance mechanisms existing within and outside the firm.

This paper is organized as follows. Section 2 presents the agency-problem based arguments in favor of publicly regulating insider trading. Section 3 shows how insider trading laws impair the system of governance within the firm. Section 4 shows how insider trading laws reduce the effectiveness of governance mechanisms outside the firm. Section 5 offers some concluding remarks.

\section{Insider Trading as Agency Problem}

Following Henry Manne's plea in favor of legalizing insider trading (Manne 1966), several authors offered several counter-arguments to justify the public regulation of insider trading. With the development of information economics and the analysis of markets with asymmetric information, some authors argued that the decision to allow or not to allow insider trading should not be left in the hands of corporate shareholders.

Focusing on the work and conclusions of the principal-agent literature, these authors argue that insider trading gives rise to agency problems that are impossible to solve

\footnotetext{
${ }^{2}$ We use the standard definition of insider trading adopted in the literature, which is the use of material nonpublic information about a corporation in a securities transaction. Insiders are traditionally defined as any individual who has access or has been given access to inside information. The American legislation uses the same definition of insider trading. However, it introduces a distinction within the class of insiders by differentiating registered (inside) insiders from (unregistered) outside insiders (tippees). Registered insiders (or corporate insiders) are defined by the Section 16 of the Securities Exchange Act of 1934 as every director and officer of the corporation plus any owners of more than $10 \%$ of the corporation's equity. They are required by the Section 16(a) to report periodically all their trade in equity securities to the SEC. Unregistered insiders (or outside-insiders) are also in possession of material nonpublic information but are not required to report their transactions to the SEC. Unregistered insiders' acquisition of inside information can be direct in the course of their work (investment bankers, lawyers, risk arbitragers, accountants, financial printers) or indirect by the intermediary of registered insiders (tippees).
} 
through self-regulation. They argue that self-regulation cannot be implemented principally because shareholders lack "adequate enforcement devices" (Easterbrook 1981, pp. 333-34; emphasis added) that can cope with the problems generated by the existence of information asymmetries and the fact that insider trading is virtually undetectable. As a consequence, agency problems emerge.

This lack of adequate enforcement mechanisms results in shareholders, particularly in corporations allowing their insiders to trade on inside information, facing agency problems associated with insider trading. Allowing insider trading provide shareholders' agents with perverse incentives that may lower long-term firm value and, consequently, harm the shareholders. Because they can profit from bad and good news without having to bear the costs of their decisions, shareholders' agents are indifferent to working to increase or to lower firm value. As a consequence, they have incentives to adopt nonvalue-maximizing behaviors (Levmore 1982, p. 149; Mendelson 1969, pp. 489-90; Posner 1978, p. 308; Schotland 1967, p. 1451). For example, they may increase the volatility of the firm's stock prices by engaging in activities involving investment and production decisions to destabilize firm performance to take advantage of stock price swings (Easterbrook 1981, p. 312; Brudney 1979, p. 156; and Masson and Madhavan 1991, p. 335).

In order to increase the volatility of the corporation's stock prices and capture the gains from stock price swings, insiders can also manipulate information about performance (Masson and Madhavan 1991, p. 334, fn. 6; Posner 1978, p. 308). They may delay transmitting material information to their superior in order to trade on it and make a profit (Haft 1982, p. 1051).

Because of all these problems, these authors argue that insider trading should be publicly regulated with no possibility of opting out in the interest of protecting shareholders against the opportunistic behaviors of unscrupulous insiders. ${ }^{3}$ As the following sections will show, insider trading laws reveal counterproductive in the sense that they aggravate the problems that they intend to mitigate.

\footnotetext{
${ }^{3}$ While it is beyond the scope of this paper, one might wonder why the government or any governmental agency would be more effective than the market in regulating insider trading if insider trading is virtually undetectable. What are those detection mechanisms that the government would implement to detect insider trading that any private organization or corporation could not?
} 


\section{The Unintended Effects of Insider Trading Laws within the Corporation}

This section investigates the impact of insider trading laws on the system of corporate governance within the corporation. It shows how insider trading laws are likely to aggravate the agency problems that insider trading may pose by discouraging active shareholding and, hence, impairing the system of corporate governance.

3.1 The Importance of Active Shareholding within the System of Corporate Governance

Active shareholding is traditionally considered a fundamental mechanism to mitigate agency problems within the corporation. Active shareholders play a key role within the system of corporate governance by internally monitoring the activity of corporation's managers. In doing so, active shareholders help mitigating agency costs and contribute to enhancing the corporation's value (Shleifer and Vishny 1986). Because they own larger blocks of stocks, large shareholders are more likely to sit on the board of directors and, hence, exercise some influence over management (Demsetz 1986, p. 313).

In addition, their position allows them to access to inside information and assess more accurately managers' performance. This ability to supervise managers' activity is important for large shareholders because they bear more risk and cost than minority shareholders, particularly in firms exhibiting high firm-specific risk. ${ }^{4}$

To be sure, active shareholding can only exist if the benefits from owning large blocks of stocks and participating actively in monitoring the management from within the corporation outweigh the costs. Alternatively, when costs of active shareholding outweigh the benefits, the incentives to take an active role in the corporate governance system disappear.

\subsection{The Effects of Insider Trading Laws on Active Shareholding}

A careful analysis of insider trading laws can show the impact of those laws on the system of corporate governance and, particularly active shareholding. Such laws have

\footnotetext{
${ }^{4}$ Firm-specific risk manifests in environments where there are frequent changes in relative prices, technology, and market shares. Such risk involves higher monitoring costs than in firms operating in environments characterized by stable prices, stable technology, and stable market shares because it is more difficult to disentangle the effects of managers' decisions on firm performance from these exogenous often unpredictable factors that also affect the firm performance (Demsetz and Lehn 1985, p. 1159). Because of this latter problem, having access to inside information becomes a crucial factor to help large shareholders to disentangle the endogenous from the exogenous effects that affect the firm performance.
} 
unintended effects on active shareholding that translate by the fact that they burden large shareholders with additional costs other than those associated with large shareholding.

For instance, in pursuance to Section 16 of the Securities Exchange Act of 1934, owners of more than $10 \%$ of equity are considered as insiders along with every officer and director of the corporation. Additionally, Section 16(a) requires them to report all their trades in equity securities on a monthly basis to the Securities Exchange Commission and the exchange if the security is registered on a national securities exchange. Section 16(b) - the insider's short-swing profit rule - prohibits insiders from trading when the purpose is to realize short-term profits, resulting from the purchase and sale of securities in a six-month period, except in very limited circumstances. ${ }^{5}$ Finally, Section 16(c) prohibits short sales of stock.

As a result, the restrictions that accompany the insider status as defined in Section 16(a) of the Securities Exchange Act of 1934 impose additional costs on large shareholders such as the reporting of their transactions, having to justify their actions, and facing potential legal costs. Alone, the short-swing profit rule imposes significant restrictions on large shareholders' trading, particularly, for the institutional investors such as corporate and pension funds, which need to protect the liquidity of their holdings. Also the short-sale prohibition can be detrimental in the sense that it does not allow large shareholders to liquidate their holdings when they received negative information.

All these additional liabilities and restrictions increase the higher risk and cost that large shareholders already incur in comparison to minority shareholders. They increase the risk for large shareholders to suffer larger losses particularly when unpredictable exogenous factors dramatically affect the firm performance. As previously explained, by sitting on the board of directors, active shareholders, benefiting from access to inside information, can timely proceed to sweeping changes when necessary. However, sometimes, short selling can be the only solution for large shareholders to minimize their losses. By prohibiting short selling, large shareholders see themselves deprived of an

\footnotetext{
${ }^{5}$ An important note regarding Section 16(b) is that it presumes that any succession of two transactions in the opposite direction (purchase/sale or sale/purchase) realized in a period less than six months, is necessarily and indisputably based on the use of inside information. As a consequence of this automatic causality established between transactions in the opposite direction and use of inside information, Section 16(b) does not require that a proof is established that there was use of inside information (George 1976, p. 40).
} 
important alternative. In addition, the benefits of having access to private information and exercising an active role in firm governance decrease in comparison to those of passive (minority) shareholders who do not have to support either the initial costs of investing in monitoring the management team or the additional costs generated by insider-trading laws but still benefit from the active role exercised by large shareholders in firm governance.

As a result, incentives for investors to hold larger blocks of stocks disappear. Instead, they prefer to keep their ownership below the $10 \%$ level and avoid triggering the insider status (Roe 1990, pp. 17-18; Seyhun 1998, p. 31). As Bhide (1993, p. 37) observes:

My interviews with corporate and pension fund managers suggest that investors are often reluctant to receive any private information from managers (let alone take on board positions) which they believe would compromise their fiduciary responsibility to protect the liquidity of their holdings. Institutions also stay below the $10 \%$ ownership limit that triggers the Section 16(b) restrictions on short-term trading. Insider trading and disclosure rules ... thus have serious consequences for governance because they limit liquidity for active stockholders: many large investors who own sizeable blocks and could play and active role are instead resolutely passive.

Moreover, by discouraging large shareholders from owning large blocks of stocks and playing an active role (by sitting on the board of directors), insider-trading laws have an impact on the structure of the board of directors and reduce board's incentives to monitor effectively the managers. Hart (1995, pp. 681-82) describes the problem as follows:

The board consists of executive directors (who are members of the management team); and nonexecutive directors, who are outsiders. On the one hand, it would hardly be reasonable to expect the directors to monitor themselves. On the other hand, nonexecutive directors may not do a very good job of monitoring for several reasons. First, they may not have a significant financial interest in the company, and they may therefore have little to gain personally from improvements in company performance. Second, nonexecutive directors are busy people (they may themselves be chief executives and sit on many boards) and probably have little time to think about company's affairs, or to collect information about the company - over and above that provided by the management. Finally, nonexecutive directors may owe their positions to management, who proposed them as directors in the first place. As well as feeling loyal to management, they may want to stay in management's good graces, so that they can be re-elected and continue to collect their fees. 
By discouraging large ownership and active monitoring by large shareholders, not only do insider trading laws change the structure of the board of directors, but they also reduce the board members' incentives in monitoring effectively the management. Instead, board members with little wealth invested in the corporation and, consequently, less interest in investing in monitoring decision-making, are more likely to collude with the management at the expense of shareholders.

The definition of inside information has also a negative impact on active shareholding. ${ }^{6}$ The American legislation as well as the European legislation define inside information as price sensitive information. The consequences are the same as with the Section 16 of the Securities Exchange Act of 1934.

To play an active role in the governance of the corporation, large shareholders or institutional investors need to have access to confidential price-sensitive information. However, playing an active role also means to become an insider and compromise the liquidity of his holdings, which is very problematic for the institutional investors and other intermediaries that have a fiduciary responsibility with regard to their own stockholders. As a consequence, large investors will refuse to receive any price-sensitive information and bar themselves from performing any active role in the corporation's governance (ISC 1991). Beny (1999) provides empirical evidence that are consistent with our argument that insider trading laws discourage large shareholders and, hence, inside monitoring. She shows that countries where insider trading laws exist and are enforced exhibit lower ownership concentration than in other countries. She also shows that the

\footnotetext{
${ }^{6}$ The literature and legal scholars tend to establish a difference between both definitions arguing that the European legislation by adopting a narrow definition of inside information creates a "grey zone," allowing insiders to trade on some inside information (Maug 1999, p. 3, 21). A careful look at both definitions shows that they are actually not different. Following the Supreme Court, the U.S. insider trading laws define inside information as "material" and "non-public." On the other hand, the European legislation defines inside information as "information which has not been made public of a precise nature relating to one or several issuers of transferable securities or to one or several transferable securities, which, if it were made public, would be likely to have a significant effect on the price of the transferable security or securities in question" (Council Directive 89/592/EEC of 13 November 1989, Article $1 \S 1$ ). The difference between both definitions would lie in the fact that the EU directive on insider trading requires inside information to be "precise." However, this distinction only appears to be a simple difference of jargon in the sense that the U.S. Supreme Court defines "material" information as information of which disclosure to the public would be likely to have an impact on the price of the security in question (George 1979, 119-126). This definition is therefore not different than the European legislation's one.
} 
tougher insider trading laws are the lower is the ownership concentration among large shareholders.

By deterring large shareholders from playing an active role in corporate governance, insider-trading laws deprive the shareholders of an important governance mechanism that inside monitoring is. Accordingly, the system of corporate governance is impaired. The effective controls on self-serving behavior from managers being weakened, corporate managers will have more latitude to make self-interested and not-necessarily-valuemaximizing decisions at the expense of the shareholders. In other words, by discouraging active shareholding, insider trading laws create the opposite of the intended effects. They do not protect shareholders against the agency problems raised by insider trading, they actually aggravate those problems.

The Counter-Argument: Collusion, Bribery, and Information Disclosure

Ernst Maug (1999) argues that allowing large shareholders to trade on inside information eliminate their incentives to monitor underperforming companies. Maug argues that in an environment where insider trading is not regulated, dominant shareholders will collude with the managers at the expense of minority shareholders. On the other hand, in a regulated environment, the interests of large shareholders are aligned with those of minority shareholders. To put it in another way, when insider trading is not regulated, managers would have incentives to communicate in advance inside information about negative developments to the large shareholders, thus allowing them to sell their stocks at inflated market prices instead of monitoring the managers. In an unregulated environment, managers are going to bribe large shareholders with information to refrain from monitoring in order to protect their rents. This collusion between large shareholders and managers will be at the expense of minority shareholders.

Moreover, Maug (1999, p. 2; emphasis added) adds:

If insider trading is prohibited, then dominant shareholders have a stronger incentive to become informed and monitor the company. Trading profits from inside information are an opportunity cost of monitoring, and prohibition of trading eliminates this opportunity cost. More precise information allows dominant shareholders to target companies accurately and to reduce the likelihood of costly interventions to that are not profitable. In the optimal environment the company has to disclose all material information to the market in a timely manner. Then outside monitors make optimal decisions, and the likelihood of monitoring and the value of 
the firm are maximized, whereas managers' benefits from control are minimized. Hence, mandatory disclosure aligns the incentives of dominant shareholders with those of small shareholders at the expense of managements' benefits from control.

According to Maug, a regulation of insider trading combined with a "maximal" mandatory disclosure policy will lead to an efficient governance system maximizing the firm value. However, Maug's reasoning does not take into account several problems that undermine his argument.

First, Maug argues that large shareholders will prefer to sell their stocks at inflated market prices than to intervene in the company because monitoring costs and its benefits are lower. Maug may be correct but there is an important variable that is likely to affect large shareholders' decision to sell their stocks. Large shareholders face significant capital gain taxes upon sale (Bhide 1993, p. 37). When this fact is taken into account, the outcome of the cost-benefit analysis is not that obvious. As Shleifer and Vishny (1986, p. 478) emphasize, large shareholders engage in monitoring because they prefer dividends while small shareholders favor capital gains because of tax considerations.

In addition, Maug overlooks the fact that, by liquidating their holdings in an unregulated environment, large shareholders send a market signal, resulting in a price change initiated by the large volume of selling, to the various market participants regarding the future value of the firm. This price signal sent to the market will also inform other investors such as outside stockholders, outside monitors or takeover specialists of the future value of the firm. On the other hand, in a regulated environment, large shareholders, because they are legally considered insiders, will hide their transactions. $^{7}$ As a consequence, market participants will receive a relatively noisier signal that is more difficult to interpret. The noisier the signal, the more difficulties will market participants have to interpret it and, therefore, the less likely an outside intervention will take place.

Another problem with Maug's argument is his assumption that by prohibiting insider trading, large shareholders will have incentives to become informed and monitor

\footnotetext{
${ }^{7}$ Seyhun and Bradley (1997: 211-14) provide empirical evidence that insiders sell in advance their stocks in firms experiencing financial difficulties and in firms filing a bankruptcy petition despite the regulation of insider trading exists. See also Meulbroek (1992) who provides evidence that the managers of some firms in financial distress sell their shares without reporting their trades to the SEC.
} 
managers' activities. As mentioned above, many large shareholders are institutional investors who need to protect the liquidity of their holdings in order to comply with the fiduciary duty that they owe to their own shareholders. Having access to confidential information is a necessity for active shareholders to monitor effectively the company performance. However, it is possible that nothing can be done to rectify the problem or it would be too costly to do so. The only solution is to sell in order to avoid suffering great losses. If large shareholders see their ability to minimize their losses in some extreme circumstances precluded, they are not going to sacrifice the liquidity of their holdings and, therefore. will reduce the size of their ownership and abstain from engaging in inside monitoring.

As we have seen, empirical evidence shows that insider-trading laws increase the dispersion of ownership. As a consequence serious problems of collective action appear. As Bhide (1993, p. 45) explains:

If the proportion of the firm's equity held by diffuse investors is subsequently increased ... liquidity increases because of the large number of stockholders. However, incentives for the blockholders to provide inside monitoring decline because the blockholders do not receive the full returns from their investment in monitoring. When stockholding is fully diffused, the firm's stock is likely to be the most liquid, but inside monitoring by stockholders is out of question.

Finally, Maug argues if the firm is compelled to disclose all material information to the public in a timely manner, outside monitors would be able to make optimal decisions in order to maximize the value of the firm. The problem with this assumption is that, again, not all material information can be released to the market. Sometimes, some material information needs to be kept confidential and cannot be revealed to the public particularly when the market where the corporation operates is very competitive.

\section{How Insider Trading Laws Affect Corporate Governance Outside the Firm}

As we have seen, insider trading laws do have detrimental effects on active shareholding. However, on might argue that active shareholding is not the only mechanism to discipline managers. Other mechanisms exist to compensate for the lack of active shareholding. Managerial competition, market for corporate control, competition, and proxy fights are examples of market-based disciplinary mechanisms. As argued in 
Padilla (2002, pp. 14-22), these mechanisms are vital to minimize managers' control and reduce their abilities to adopt opportunistic behaviors. For example, Rappaport (1990, p. 5) states:

It is impossible to overstate how deeply the market for corporate control has changed the attitudes and practices of U.S. managers. ... It represents the most effective check on management autonomy ever devised.

However, even if the takeover mechanism can be a powerful mechanism to discipline the managers, it cannot substitute for active shareholding. As Bhide (1993, p. 44) comments:

Acquirers who make unsolicited tender offers operate under significant informational constraints: they have to raise money deal by deal, making their case from publicly available data. Even at the peak in 1985-1987, these acquirers posed a threat to only a small number of diversified firms whose break-up values could be reliably determined from public data to be significantly higher than their market values.

Moreover, insider trading laws also have unintended consequences on takeover mechanism that may impair its effectiveness. Beny (1999) shows that, by reducing ownership concentration, insider trading laws increase indirectly the cost of acquiring a majority of shares in a given company. In the context of takeovers, less ownership concentration increases the benefits from free riding and makes acquisitions more expensive (Bris 2000, p. 18; Scharfstein 1988, pp. 194-95).

Insider trading laws, by reducing ownership concentration and discouraging active monitoring, have also a serious impact on the proxy fight mechanism, which is used to remove an "inefficient" board of directors. Active monitoring and proxy fights are closely interconnected mechanisms when there are costs to find that the company is underperforming. These mechanisms are also used to explain company's underperformance. These costs are usually lower for active shareholders because they sit on the board of directors and have regular access to the kind of information necessary to perform this kind of tasks, namely, confidential information. On the other hand, these costs become higher for passive shareholders who do not access such information because they are not members of the board of directors.

Furthermore, the more dispersed the ownership, the more costly it is to locate the names and addresses of shareholders, to mail out ballots, and to persuade each 
shareholder of the merits of the dissident slate. On the other hand, the benefits of an improved management will accrue to all shareholders. As a consequence, if the dissident, after performing his "cost-benefit analysis", believes that his costs are higher than the expected benefits of launching a proxy fight, he will not launch the proxy fight and, instead will liquidate his assets. Moreover, since the benefits of an improved management are shared by all shareholders, free riding problems are also likely to arise, and the proxy fight is more likely to fail if small shareholders rationally refuse to undertake the proxy fight (Hart 1995, pp. 682-83). Consequently, the management feeling immune to such a mechanism is going to take advantage of its entrenched position and make self-serving discretionary decisions.

Passive shareholders, outside stockholders, analysts, or takeover specialists suffer from a disadvantage in comparison to active shareholders. They do not have the same access (or costs to access) to the inside information required to properly disentangle the endogenous effects (those resulting from managerial decisions) from the exogenous effects (those due to unpredictable random factors) that affect the firm's performance (Bhide 1994, p. 136). Accessing inside information is however a crucial factor to perform effective monitoring and effectively implement the necessary measures in a timely manner. Therefore, the higher the costs of accessing such information and disciplining the management, the lower the likelihood that these individuals are going to make costly decisions to displace entrenched managers pursuing their own interests at the expense of stockholders. This is true, particularly if these individuals have to share the benefits of their actions with other free-riding shareholders. The general result does not vary because entrenched managers will benefit from this situation and continue to make self-serving decisions at the expense of shareholders.

An additional problem arises through another insider trading law. By preventing anyone in possession of inside information from trading in the securities of firms involved in a takeover, Rule 14e(3) limits the ability of acquirers to have recourse to arbitrageurs to assemble blocks easily. 


\section{Conclusion}

Some authors argue that insider trading gives rise to agency problems impossible to solve through self-regulation. They argue that self-regulation cannot be efficiently implemented because corporate shareholders lack adequate enforcement devices. Therefore, they maintain that public regulation of insider trading should be implemented.

This paper offers a novel argument in the debate on insider trading by analyzing the unintended effects of insider trading laws on the system of corporate governance within and outside the firm. The analysis shows that outlawing of insider trading cannot but produce the opposite of the intended effects. Insider trading laws have detrimental effects on the system of corporate governance and aggravate existing agency problems within the corporation.

Such analysis also draws some implications for further empirical research on insider trading. There is no doubt that both insider trading and insider trading laws have (agency) costs. Ultimately the question to answer is: are agency costs associated with insider trading higher or lower than the agency costs associated with insider trading laws? 


\section{REFERENCES}

Beny, Laura N. 1999. "A Comparative Empirical Investigation of Agency and Market Theories of Insider Trading." Discussion Paper No. 264. Cambridge, Mass.: Harvard Law School, James M. Olin Center for Law, Economics, and Business.

Http://www.law.harvard.edu/programs/olin_center/papers/pdf/264.pdf.

Bhide, Amar. 1993. "The Hidden costs of stock market liquidity." Journal of Financial Economics 34: 31-51.

Bhide, Amar. 1994. "Efficient Markets, Deficient Governance." Harvard Business Review (November-December): 129-39.

Bris, Arturo. 2000. "Do Insider Trading Laws Work?" Yale ICF Working Paper No. 00-19. Http://papers.ssrn.com/sol3/papers.cfm?abstract_id=248417.

Brudney, Victor. 1979. "Insiders, Outsiders and Informational Advantages under the Federal Securities Laws." Harvard Law Review 93: 322-76.

Code of Federal Regulations. 2001. 17 CFR240.14e-3. Http://frwebgate.access.gpo.gov/cgi-bin/getcfr.cgi?TITLE $=17 \&$ PART $=240 \&$ SECTION= $14 \mathrm{e}-3 \& Y E A R=2000 \& \mathrm{TYPE}=\mathrm{TEXT}$.

Council Directive 89/592/EEC coordinating regulations on insider trading in Europe. 1989. Http://europa.eu.int/eur-lex/en/lif/dat/1989/en_389L0592.html.

Demsetz, Harold. 1986. "Corporate Control, Insider Trading, and Rates of Return." American Economic Review 76(2): 313-16.

Demsetz, Harold, and Kenneth Lehn. 1985. "The Structure of Corporate Ownership: Causes and Consequences." The Journal of Political Economy 93(6): 1155-1177.

Easterbrook, Frank H. 1981. "Insider Trading, Secret Agents, Evidentiary Privileges, and the Production of Information." Supreme Court Review: 3-24.

Easterbrook, Frank H. 1985. "Insider Trading as an Agency Problem." In Principals and Agents: The Structure of Business. John W. Pratt and Richard J. Zeckhauser, eds. Boston: Harvard Business School Press. Pp. 81-99.

George, Alain. 1976. L'utilisation en bourse d'informations privilégiées dans le droit des EtatsUnis. Paris: Economica.

Haft, Robert J. 1982."The Effect of Insider Trading Rules on the Internal Efficiency of the Large Corporation." Michigan Law Review 80: 1051-71.

Hart, Oliver. 1995. "Corporate Governance: Some Theory and Implications." The Economic Journal 105(430): 678-89. 
Institutional Shareholders' Committee. 1991. The Responsibilities of Institutional Shareholders in $U K$. December.

Http://www.ivis.computasoft.com/Files.nsf/Lookup/ISCResponsibilities/\$file/ISCRes ponsibilities.htm

Levmore, Saul. 1982. "Securities and Secrets: Insider Trading and the Law of Contracts." Virginia Law Review 68: 117-60.

Manne, Henry G. 1966. Insider Trading and the Stock Market. New York: The Free Press.

Masson, Robert T. and, Ananth Madhavan. 1991. "Insider Trading and the Value of the Firm." The Journal of Industrial Economics 39(4): 333-53.

Maug, Ernst. 1999. "Insider Trading and Corporate Governance." Research Paper. Http://www.duke.edu/ maug/research/inside/insider.pdf

Mendelson, Morris. 1969. "The Economics Board of Insider Trading Reconsidered." University of Pennsylvania Law Review 117: 470-92.

Meulbroek, Lisa K. 1992. "An Empirical Analysis of Illegal Insider Trading." The Journal of Finance 47(5): 1661-1699.

Padilla, Alexandre. 2002. "Can Agency Theory Justify the Regulation of Insider Trading?" The Quarterly Journal of Austrian Economics 5(1): 3-38.

Padilla, Alexandre. 2003. Insider Trading, Agency Theory, and Corporate Governance. Unpublished Ph.D. dissertation. Université de Droit, d'Economie, et des Sciences d'Aix-Marseille 3, Aix-en-Provence, France.

Posner, Richard A. 1977. Economic Analysis of Law. $2^{\text {nd }}$ ed. Boston: Little Brown.

Rappaport, Alfred. 1990. "The Staying Power of the Public Corporation." Harvard Business Review January-February, 10 pages. Available online at:

Http://www.mhhe.com/ads-gi/viewer.pl/0075287218.PDF?page=1\&mode=nppiic100

Roe, Mark J. 1990. "Political and legal restraints on ownership and control of public companies." Journal of Financial Economics 27: 7-41.

Scharfstein, David. 1988. "The Disciplinary Role of Takeovers." Review of Economic Studies 55(2): 185-99.

Schotland, Roy A. 1967. "Unsafe At Any Price: A Reply to Manne, Insider Trading and the Stock Market." Virginia Law Review 53: 1425-78.

Securities Exchange Act of 1934. 2004.

Available at: Http://www.sec.gov/about/laws/sea34.pdf 
Seyhun, H. Nejat. 1998. Investment Intelligence from Insider Trading. Cambridge, Mass: MIT Press.

Shleifer, Andrei, and Robert W. Vishny. 1986. "Large Shareholders and Corporate Control." Journal of Political Economy 94(3): 461-88. 